\title{
The Relationship Between Industrial Production Index, Oil Prices and Consumer Price Index in the Turkish Economy
}

\author{
Türkiye Ekonomisinde Sanayi Üretim Endeksi, Petrol Fiyatları ve Tüfe \\ Arasındaki iliş̧ki
}

\section{Haydar KARADAĞ ${ }^{1}$ [D}

\begin{abstract}
Countries trying to increase their production in the industrial sector wish to have access to cheap energy. However, a rise in oil prices affects the industrial production of countries dependent on oil. Furthermore, as production costs increase, the general level of prices also increases. This study aims to examine the long-term effects of the rise in oil prices on the industrial production index and the CPI in the Turkish economy. Since the study measures the impact of Brent crude oil prices on the industrial production index and CPI for the Turkish economy, it contributes to the literature. In this respect, the study investigated the relationships among the specified variables for the 2010: Q1-2020: Q4 period of the Turkish economy. Phillips-Ouliaris cointegration test and Granger and Bootstrap causality test were used to analyze the relationship among the variables. A long-term relationship was found between the variables. According to the results of both causality tests, it was determined that the rise in oil prices raised the $\mathrm{CPI}$ by increasing the cost of industrial production in the Turkish economy. The findings show that oil prices should be monitored closely by actors of economic management.
\end{abstract}

Keywords: Industrial production index, Oil price, Consumer price index, Bootstrap causality test, Turkish economy

Jel Code: C12, E31, L11, Q41
DOI: $10.26650 / J E P R 913986$

'Dr. Öğr. Üyesi, Recep Tayyip Erdoğan Üniversitesi, İktisadi ve İdari Bilimler Fakültesi, İktisat Bölümü, Rize, Türkiye

ORCID: H.K. 0000-0003-2398-7314

Corresponding author/Sorumlu yazar: Haydar KARADAĞ,

Recep Tayyip Erdoğan Üniversitesi, Iktisadi ve İdari Bilimler Fakültesi, Zihni Derin Yerleşkesi

Fener Mh., Rize-Türkiye

E-mail/E-posta:

haydar.karadag@erdogan.edu.tr

Submitted/Başvuru: 12.04.2021

Revision Requested/Revizyon Talebi: 08.05.2021

Last Revision Received/Son Revizyon:

15.05.2021

Accepted/Kabul: 17.05.2021

Citation/Atıf: Karadag, H. (2021). The relationship between industrial production index, oil prices and consumer price index in the turkish economy. Iktisat Politikası Araştırmaları Dergisi - Journal of Economic Policy Researches, 8(2), 211-223.

https://doi.org/10.26650/JEPR913986 


\section{Introduction}

The industrial sector plays a vital role in increasing production and employment in competing economies. An increase in industrial production increases the GDP of countries and creates positive effects on macroeconomic indicators (Güder \& Kahıloğulları, 2015, p. 365). Economies aim to produce qualified production by attaching importance to technological advances. In addition, they aim to increase the investment volume in the economy by encouraging foreign investors. In this way, they reduce the unemployment rate in the country by providing new employment opportunities (Kalkavan, Eti, \& Yüksel, 2020, p. 57).

The need for energy increases with the population growth, urbanization, industrialization, and developing technology. Since the inability to respond to this increasing demand has caused significant economic problems for many countries, especially in economic terms, the focus has been shifted to balancing supply-demand in recent years. In order to prevent potential bottlenecks in energy derived from oil, coal, hydraulic, natural gas, nuclear, and renewable energy sources, regular planning is done in production, transmission, and distribution systems (Haliloğlu \& Tutu, 2018, p. 243).

Energy, which is the primary input of industrial production, plays a vital role in the economic development of, especially, oil countries (Güder \& Kahıloğulları, 2015, p. 365). A rise in oil prices reduces the demand for consumption and investment goods. The rising price of oil erodes the foreign exchange reserves in oil-importing countries, increasing the current account deficit in these economies (Gündoğan \& Tok, 2019, p. 131-132). To what extent oil price shocks impact a country's economy varies according to the level of dependence on oil and the share of oil expenditures in national income (Karadaş \& Koşaroğlu, 2019, p. 42).

Changes in the price of an essential input in industrial production such as petroleum directly affect industrial production. Furthermore, rising oil prices adversely affect the real economy. In particular, in countries such as Turkey, where current account deficits are financed through borrowing, a rise in oil prices leads to macroeconomic instability. It also increases production costs and creates cost-push inflation. When the increased production costs are reflected in sales prices, consumer welfare is negatively affected in the final analysis (Gündoğan \& Tok, 2019, p. 131-132). Oil prices also create uncertainty in the market, which leads to a rise in production costs. In this way, both consumption and cash flows to manufacturing companies decrease. As a result, companies also reduce their investments. (Dursun \& Özcan, 2019, p. 180).

After a short introduction, the second section of this study examines the relationship 
between industrial production index, oil prices, and CPI. In the third section, the literature on the relationship between industrial production index, oil prices, and CPI is presented. In section 4, an empirical analysis is performed, and the findings obtained are evaluated. In the concluding section, the findings obtained are interpreted.

\section{Industrial Production Index, Oil Price, and CPI Relations}

The increase in demand for oil in turn the demand for industrial commodities in which oil is used as input (Y1ldırım, Bayar, \& Kaya, 2014, p. 103). Changes in oil prices also affect the consumer price index (Eyüboğlu \& Eyüboğlu, 2016, p. 150). Nevertheless, the increase in the growth rate of the economy also increases the oil demand (Uçan \& Bozkaya, 2019, p. $650)$.

Increasing oil consumption causes inflation in both demand and costs (Erkuş \& Karamelikli, 2016, p. 3). Import countries that do not possess sufficient energy resources become dependent on oil prices because they do not implement the right economic policies. This condition results in the fragility of the economic structure of importing economies. According to the Demand-Side Approach, the increase in oil prices causes a decrease in consumption expenditures and an increase in the production costs of domestic investments. Increasing production costs and decreasing consumption expenditures reduce foreign investments in the country. According to the Monetary Policy approach, the rise in oil prices increases inflation. In order to control increasing inflation, actors of economic management apply tight monetary policies, which causes an increase in interest rates while at the same time effecting a decrease in economic growth (Tütüncü \& Kahveci, 2020, p. 849).

\section{Graph 1: Relationship between Industrial Production Index, Brent Oil Price, and CPI}

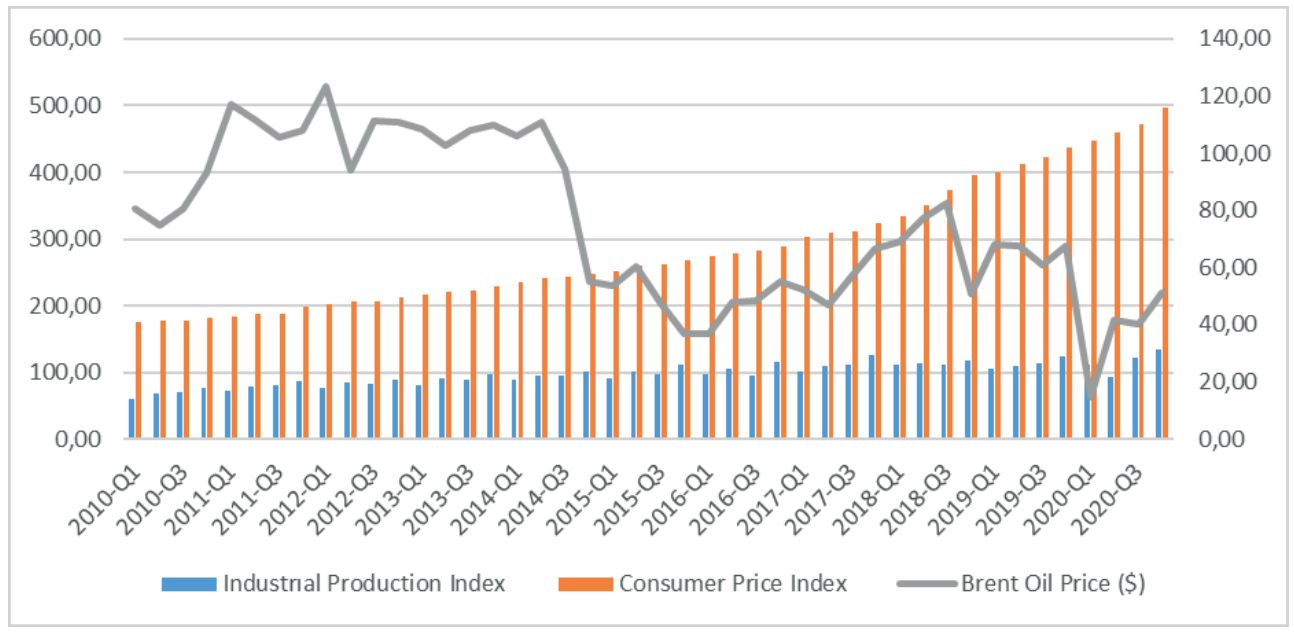

Source: Central Bank of the Republic of Turkey (CBRT), https://evds2.tcmb.gov.tr/index.php?/evds/serieMarket (15.02.2021). 
When Graph 1 is analyzed, it is seen that Brent oil prices were in the range of ' $\$ 100-120$ ' in the 2010-2014 period. In 2014, oil prices started to decline and dropped to a level of $\$ 40$ in 2016. Oil prices, which started to rise again as of 2017, dropped to a level of 15 during the COVID-19 pandemic in 2020. As for the Consumer Price Index, a steady increase was observed between 2020 and 2021 while the Industrial Production Index moved at a stable level. The Industrial Production Index in the Turkish economy dropped at the beginning of the year 2020. As for the remaining periods of 2020, the industrial production index started to increase. When Graph 1 is analyzed, it is noteworthy that the changes do not influence the industrial production index and the consumer price index in oil prices. Even in the period between 2010 and 2020, when oil prices increased or decreased, it is seen that the consumer price index constantly increased. Nevertheless, despite the change in oil prices, the industrial production index generally moved at a stable level.

\section{Literature Review}

The impact of oil prices on industrial production and inflation is an issue that requires measures in terms of employment and price stability. Various studies have been conducted in the literature to measure the impact of oil prices on industrial production and inflation in economies. In this context, one of the studies investigating the impact of oil price changes on inflation using the Benchmark Model, conducted by LeBlanc and Chinn (2004), revealed that the $10 \%$ increase in oil prices increased the inflation rate of England, the USA, Japan, France, and Germany by 0.1 to $0.8 \%$ in 1980: Q1-2001: Q4 period. In their study conducted on 6 Asian countries, implementing the Granger Causality Test, Cunado and Gracia (2005) concluded that the change in oil prices significantly impacted consumer price indices for the period 1975-2002. Cologni and Manera (2008) examined the direct effects of oil price shocks on prices with a structural cointegrated VAR model for the G-7 countries for the period 1980: Q1-2003: Q4. According to the estimated coefficients of the structural part of the model, it was found that oil prices affected the inflation rate for all countries except Japan and the UK. Ahmed and Wadud (2011) used a structural VAR (SVAR) model based on monthly data for the period 1986-2009 of the Malaysian economy. According to the model estimates, declines in oil prices lowered the levels of the Consumer Price Index (CPI). Dynamic impulse response functions obtained from the SVAR model revealed a long-term slowing down effect of oil price volatility shock on Malaysian industrial production. Zhao, Zhang, Wang, and $\mathrm{Xu}$ (2016) established the dynamic stochastic general equilibrium (DSGE) model for the Chinese economy for 1990-2013. According to the simulation results, oil supply shocks caused by political events had a short-term effect on production and inflation in China. The demand shocks in the crude oil market contributed to the fluctuations in China's production and inflation. Sek (2017) investigated the symmetrical and asymmetrical pass-through effect of oil price changes into the domestic price index in 
Malaysia. He used linear and nonlinear autoregressive distributed lag (ARDL) models for the period 1980-2015 to examine the effect in question. The results showed that changes in oil prices have symmetrical and asymmetrical pass-through effects on domestic prices across sectors. Changes in oil prices lead to higher output growth. On the other hand, they have a limited effect on consumer prices in the long run. Koçak, Balan, and Albayrak (2017) researched the relationship between oil prices in countries that import oil for the period 2003:01-2017:02 and inflation using the VAR model. A positive long-term relationship is detected between oil prices and inflation at the end of the analysis. According to Granger Causality test results, it is understood that inflation is the Granger reason for oil prices. Bayraktutan and Solmaz (2019) analyzed the inflationist impact of oil prices in 20 countries which import the most oil. The annual data of 1993-2007 are analyzed with the panel data method, and it is concluded that oil prices are a tonic for inflation.

A study examining the effect of the change in oil prices on industrial production was conducted by Ayadi in 2005. Employing a VAR analysis of the Nigerian economy from 1980 through 2004, the said study revealed that the change in oil prices did not affect industrial production. However, in Kumar's study (2009), the VAR analysis demonstrated that the increase in oil prices negatively affected industrial production in the Indian economy during 1975-2004.

Among the studies conducted on the Turkish economy, Özdemir and Akgül (2015) investigated the industrial production index and the changes in oil prices with Markov Exchange Vector Autoregressive (MS-VAR) models using the monthly data of 2005:102014:02. As a result of the study, they found that oil and gasoline prices impacted industrial production. Gokmenoglu, Azin, and Taspinar (2015) examined the relationship among oil price, inflation, GDP, and industrial production for 1961-2012. In order to investigate the relationship between variables, they employed three different tests: unit root, cointegration, and causality tests. Johansen cointegration results confirmed that there was a long-run relationship between these variables. The Granger causality test illustrated a unidirectional relationship from oil price to industrial production. For the 2003-2015 period, Erkuş and Karamelikli (2016) conducted ARDL for a long-term symmetrical analysis of crude oil prices and their effects on inflation while also employing NARDL to test the nonlinear effects. As a result, they found that the increase in oil prices positively affected consumer prices. Yildırtan and Berk (2017) examined the relationship between the current account deficit, consumer price index, and industrial production index to analyze the long-term effects of the decrease in oil prices on the Turkish economy. The causality between the oil prices in January 2005 and August 2016 and macroeconomic variables was tested by VAR Granger Causality/Block Exogeneity Wald Test. The analysis results show the highest correlation with the crude oil price index, industrial production index, and consumer price index. 
Uçan and Bozkaya (2019) examined the effects of oil price changes on macroeconomic variables in the 2000:Q1-2018:Q1 period. According to the cointegration test results, impulse-response analysis, and causality test, the change in oil prices is not severe on both the industrial production index and the consumer price index. However, the consumer price index is more affected by the changes in oil prices. Karadaş and Koşaroğlu (2019) employed structural VAR (SVAR) analysis to examine the long-term effects of structural shocks in oil prices on the economy for the period 2005:01-2018:07. A structural shock in oil prices explained about $44 \%$ of the changes in the industrial production index. Therefore, the oil price spikes cause the industrial production in Turkey to decrease; thus, negatively affecting the economy. Tütüncü and Kahveci (2020) analyzed the effects of oil prices on industrial production index and unemployment for 2006:1-2018:12 using Hacker and Hatemi-J symmetric and asymmetric causality tests. They found a causality relationship from oil prices to the industrial production index between 2007:08-2015:06 and 2017:01-2018:05.

\section{Data Set, Methodology, and Findings}

In this study, the relationship between industrial production index, oil prices, and the CPI for 2010: Q1-2020: Q4 of the Turkish economy was analyzed. The data of the study were obtained from the database of the CBRT, "evds.tcmb.gov.tr." The industrial production index was shown in the study as 'IPI', oil prices as 'BRENT', and consumer price index as 'CPI'.

In a situation where the examined variables are expected to be in a nonlinear form, linear and nonlinear unit root tests are employed, and the test results are compared. For this reason, ADF unit root tests were conducted to test the unit root and stationarity of the series (Destek \& Okumuş, 2016, p. 77). If there is a break in the series, the results of the ADF unit root tests tend to confirm the hypothesis that the series has a unit root (Gövdeli, 2016, p. 226). Before conducting the causality analysis, possible breaks are taken into account using the augmented Dickey-Fuller (ADF) test from the conventional unit root tests. Regressions for the ADF unit root test are as follows (Yavuz, 2006, p.163-164).

$$
\begin{gathered}
\Delta y_{t}=\alpha+\beta T+\varphi y_{t-1}+\sum_{i=1}^{k} \delta_{i} \Delta y_{t-i}+u_{t} \\
\Delta y_{t}=\alpha+\varphi y_{t-1}+\sum_{i=1}^{k} \delta_{i} \Delta y_{t-i}+u_{t}
\end{gathered}
$$

With the estimation of the above equations, whether the variable $y_{t}$ has a unit root is tested. The $\mathrm{T}$ in Equation 1 indicates the deterministic trend. The lag difference terms are included in the model to ensure that the error term does not contain autocorrelation. In Equation 1, the basic hypothesis that the variable $y_{t}$ has a unit root versus the alternative that the trend is stationary is tested. In Equation 2, the basic hypothesis that the variable $y_{t}$ has a unit root is tested against the alternative that it is stationary around a mean. Accordingly: 


$$
\mathrm{H}_{0}=\varphi=0, \quad \mathrm{H}_{1}=\varphi<0
$$

If the $\varphi$ estimation is not different from the null, the unit root hypothesis cannot be rejected. If $\varphi<0$, the $y_{t}$ variable's alternative trend-stationarity or mean-stationarity hypotheses are accepted (Yavuz, 2006, p. 164).

Table 1: ADF Unit Root Test Results

\begin{tabular}{lccc}
\hline & & Level Values & \multicolumn{1}{c}{ First Differences } \\
\cline { 2 - 4 } & Variables & ADF & ADF \\
\cline { 2 - 4 } Test Statistics (With & lntufe & $-0,7665(0)$ & $\mathbf{- 6 , 3 8 2 3 ( \mathbf { 0 } ) * * *}$ \\
Stationary \&Trend) & lnbrent & $-2,6009(0)$ & $\mathbf{- 9 , 5 7 9 6 ( \mathbf { 0 } ) * * *}$ \\
& lnsue & $-1,7541(3)$ & $\mathbf{- 1 0 , 3 1 4 0 ( 2 ) * * *}$ \\
Critic Values & $\% 1$ & -4.186481 & -4.192337 \\
& $\% 5$ & -3.518090 & -3.520787 \\
& $\% 10$ & -3.189732 & -3.191277 \\
\hline
\end{tabular}

Note: Values in the brackets mean gap lengths for ADF. Schwarz Information Criteria (SIC) was used to choose the gap lengths. *** means that the significance level is $1 \%$.

According to Table 1, all series contain unit root in level values. Therefore, according to the results of the ADF Unit Root Test in Table 1, it was seen that all the variables examined in the study became stable at first difference. The appropriate lag length was determined for the series that became stationary, shown in Table 2.

Table 2: VAR Lag Length Selection

\begin{tabular}{lcccccc}
\hline Lag & LogL & LR & FPE & AIC & SC & HQ \\
\hline 0 & 24.47557 & NA & $6.86 \mathrm{e}-05$ & -1.073778 & -0.947112 & -1.027980 \\
1 & 156.1102 & 236.9424 & $1.49 \mathrm{e}-07$ & -7.205511 & $-6.698847^{*}$ & -7.022317 \\
2 & 168.4907 & 20.42772 & $1.27 \mathrm{e}-07$ & -7.374533 & -6.487871 & -7.053944 \\
3 & 175.6555 & 10.74730 & $1.42 \mathrm{e}-07$ & -7.282776 & -6.016117 & -6.824792 \\
$\mathbf{4}$ & $\mathbf{1 9 5 . 7 3 4 7}$ & $\mathbf{2 7 . 1 0 6 8 6 ^ { * }}$ & $\mathbf{8 . 5 3 e - 0 8 *}$ & $\mathbf{- 7 . 8 3 6 7 3 4 ^ { * }}$ & $\mathbf{- 6 . 1 9 0 0 7 7}$ & $\mathbf{- 7 . 2 4 1 3 5 5 *}$ \\
\hline
\end{tabular}

Note: * indicates lag order selected by the criterion, LR: sequential modified LR test statistic (each test at $5 \%$ level), FPE: Final prediction error, AIC: Akaike information criterion, SC: Schwarz information criterion, HQ: Hannan-Quinn information criterion

Before moving on to the empirical analysis, the lag length according to the VAR model is presented in Table 2. In Table 2, the lag length was determined as four according to the VAR model. After determining the lag length, the cointegration analysis, which provides the longrun relationship, was conducted. In this study, the Phillips-Ouliaris cointegration test was conducted since it yields better results when the series contains sequential dependencies and different variance (Öruç, 2017, p. 270; Sadeghzadeh, 2018, p. 244). Phillips-Oularis cointegration test yields the model estimated in the equation. 


$$
\begin{gathered}
y_{t}=\mu_{t}+\beta_{1} x_{1 t}+\beta_{2} x_{2 t}+\ldots+\beta_{k} x_{k}+u_{t} \\
u_{t}=\rho u_{t-1}+\varepsilon_{t}
\end{gathered}
$$

The explanatory variables in the model $\left(x_{t}\right)$ are subject to regression on the explained variable, and error terms are created. In the second stage, the obtained error terms are estimated on their past values. The null hypothesis $\rho=1$ is tested (Öruç, 2017, p. 270).

Phillips-Ouliaris has developed two residual-based tests; the 'tau-statistic' and the 'z-statistic'. Both tests are used in the same way as unit root tests. However, the data are the residuals obtained from the cointegration regressions. In these tests, the null hypothesis that there is no cointegration is tested against the alternative hypothesis that there is cointegration (Ecevit \& Çetin, 2016, p. 89).

Table 3: Phillips Oullaris Cointegration Results

\begin{tabular}{lcccc}
\hline Null hypothesis: Series are not cointegrated & & & \\
\hline Dependent & tau-statistic & Prob.* & z-statistic & Prob.* \\
\hline LNTUFEF & -4.395792 & $\mathbf{0 . 0 1 8 3}$ & -27.31599 & $\mathbf{0 . 0 1 2 7}$ \\
\hline
\end{tabular}

Note: *MacKinnon (1996) p-values. Long-run variance estimate (Prewhitening with lags = 4, Bartlett kernel, Newey-West fixed bandwidth)

According to Table 3, there is a cointegration relationship among the variables. In other words, a long-term relationship was found between the variables. Accordingly, the null hypothesis claiming that there is no cointegration relationship was rejected.

After the Phillips-Ouliaris cointegration test, a causality relationship between the series was examined with the Granger causality test. If the past of a random variable $\mathrm{X}$ provides a better estimation of another random variable $\mathrm{Y}$, variable $\mathrm{X}$ is the Granger-cause of $\mathrm{Y}$. The estimation is made after considering all the other possible and non-random data (Atukeren, 2011, p. 137-138). In the Granger causality test, variables are not separated as dependent or independent, and the interaction between variables is analyzed simultaneously (Doğan, Eroğlu, \& Değer, 2016, p. 413). The Granger test is shown as an error correction model of a co-integrated system (Atukeren, 2011, p. 139).

$$
\begin{aligned}
\Delta y_{t} & =\Sigma \delta_{1, i} \Delta y_{t-1}+\Sigma \beta_{1, i} \Delta x_{t-1}+\gamma_{1} z_{t-1}+\mu_{1 t} \\
\Delta x_{t} & =\Sigma \delta_{2, i} \Delta y_{t-1}+\Sigma \beta_{2, i} \Delta x_{t-1}+\gamma_{2} z_{t-1}+\mu_{2 t}
\end{aligned}
$$

$\Delta$ is difference operator, and, $\mu_{1 t}$ and $\mu_{2 t}$ error terms conforming to the classical

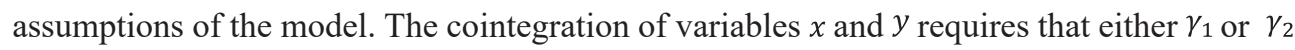
in models (5) and (6) must be non-zero. Therefore, in the error correction model, the changes in the dependent variable are partially determined by the lagged value of $z$. However, the 
fact that $z_{t-1}$ includes $x_{t-1}$ and $y_{t-1}$ indicates that at least one variable of the cointegration relationship is the Granger-cause of the other.

Table 4: Granger Causality Test Results

\begin{tabular}{lccc}
\hline Sample: 144 & & & \\
Lags: 4 & Obs & F-Statistic & Prob. \\
\hline Null Hypothesis: & 40 & 4.53815 & $\mathbf{0 . 0 0 5 3 * * *}$ \\
\hline LNBRENT does not Granger Cause LNTUFE & & 1.99996 & 0.1191 \\
LNTUFE does not Granger Cause LNBRENT & & 4.53815 & $\mathbf{0 . 0 0 5 3 * * *}$ \\
LNSUE does not Granger Cause LNTUFE & 40 & 6.45715 & $\mathbf{0 . 0 0 0 7 * * *}$ \\
LNTUFE does not Granger Cause LNSUE & & 1.99996 & 0.1191 \\
LNSUE does not Granger Cause LNBRENT & 40 & 6.45715 & $\mathbf{0 . 0 0 0 7 * * *}$ \\
LNBRENT does not Granger Cause LNSUE & & &
\end{tabular}

Table 4 shows the Granger causality test results. According to the Granger causality test results, there is a unidirectional causality running from Brent oil prices to CPI. In other words, the increase (decrease) in Brent oil prices increases (decreases) the CPI. There is bidirectional causality between the industrial production index and the CPI. Increase (decrease) of the industrial production index increases (decreases) the CPI. Similarly, the increase (decrease) of the CPI increases (decreases) the industrial production index. Again, there is a unidirectional causality running from Brent oil prices to the industrial production index. An increase (decrease) in Brent oil prices increases (decreases) the industrial production index.

In the study, after the Granger causality test, the relationship among variables was analyzed using the Bootstrap causality test. Critical values are provided with Bootstrap when errors are not normally distributed. However, the inability to separate positive and negative shocks is a weakness of this model. In this context, in the asymmetric causality test developed by Hatemi-J (2012), the responses of the series to negative and positive shocks are examined separately (Bektur \& Malcıoğlu, 2017, p. 80). The causality relationship between the variables is analyzed by Hatemi-J (2012) bootstrap causality test. The results obtained with this method are more reliable than other methods, especially when the sample size is small (Kızılkaya, 2018, p. 222). 
Table 5: Bootstrap Causality Test Results

\begin{tabular}{lccccc}
\hline Hypothesis & $\begin{array}{c}\text { Optimum } \\
\text { VAR Gap } \\
\text { Length } \\
\left(\mathbf{k}+\mathbf{d}_{\text {max }}\right)\end{array}$ & $\begin{array}{c}\text { MWALD } \\
\text { Statistics }\end{array}$ & $\begin{array}{c}\mathbf{1 \%} \text { Critical } \\
\text { Value }\end{array}$ & $\begin{array}{c}\mathbf{5 \%} \text { Critical } \\
\text { Value }\end{array}$ & $\begin{array}{c}\mathbf{1 0 \%} \\
\text { Critical } \\
\text { Value }\end{array}$ \\
\hline Inbrent $\neq>$ Intufe & 4 & $\mathbf{1 2 , 2 9 2 * *}$ & 19,592 & 11,909 & 9,265 \\
Intufe $\neq>$ Inbrent & 4 & 1,093 & 18,409 & 11,844 & 9,124 \\
Insue $\neq>$ Intufe & 4 & $\mathbf{1 1 , 4 8 6 ^ { * }}$ & 18,314 & 11,757 & 9,162 \\
Intufe $\neq>$ Insue & 4 & $\mathbf{1 4 , 4 6 5 * *}$ & 20,217 & 12,987 & 10,361 \\
Inbrent $\neq>$ Insue & 4 & $\mathbf{1 4 , 4 6 5 * *}$ & 18,166 & 11,710 & 9,164 \\
Insue $\neq>$ Inbrent & 4 & 0,903 & 17,442 & 11,333 & 8,974 \\
\hline
\end{tabular}

Note: $\neq>$ notation on the table shows the hypothesis that there is no Granger causality relationship between the two variables in the direction given. Gap length is specified based on the SIC criterion.

$* * *, * *$, and $*$ mean that the significance level is $1 \%, 5 \%$, and $10 \%$, respectively.

Table 5 shows Bootstrap causality test results. According to the Bootstrap causality test results, there is a unidirectional causality running from Brent oil prices to CPI. In other words, the increase (decrease) in Brent oil prices increases (decreases) the CPI. There is bidirectional causality between the industrial production index and the CPI. An increase (decrease) in the industrial production index also increases (decreases) the CPI. Similarly, the increase (decrease) in the CPI increases (decreases) the industrial production index. Again, there is a unidirectional causality running from Brent oil prices to the industrial production index. An increase (decrease) in Brent oil prices increases (decreases) the industrial production index. Thus, it was observed that there was consistency between the results of the Bootstrap and the Granger causality tests.

\section{Conclusion}

The level of industrialization in a country is an indicator of its development. Countries trying to increase their industrial production prefer to have access to energy cheaply and easily. However, an increase in oil prices affects the industrial production of countries that are dependent on oil. Furthermore, an increase in production costs also increases the general level of prices. The increase in prices reduces consumers' welfare level, thus lowering their demands, leading to economic recession.

Countries with a strong dependence on oil are macroeconomically vulnerable to oil price changes. While rises in oil prices affect the economy negatively, low oil prices affect the economy positively. In this context, this study investigated the relationship between the industrial production index, Brent crude oil prices, and CPI using the quarterly data of the period 2010:Q1-2020:Q4 in the Turkish economy. Accordingly, the stationarity of the series 
was tested with the ADF unit root test, and it was determined that the series became stationary by taking the difference. As the series became stationary at the same level, the Phillips-Ouliaris cointegration test, which provides the long-run relationship, was conducted. According to the Phillips-Ouliaris cointegration test results, there is a long-term cointegrated relationship between the variables studied. Later in the study, the Granger causality test and Bootstrap causality test were performed. It was observed that there was consistency between the results of the Bootstrap and Granger causality tests. According to the results of both tests, it was seen that the rise in oil prices increased production costs; thus, raising the CPI in the period 2010: Q1-2020: Q4 in the Turkish economy. The results obtained in this study are consistent with the findings of Uçan and Bozkaya (2019), and Karadaş and Koşaroğlu (2019) regarding the Turkish economy.

As a result of the study findings, it could be argued that oil prices should be monitored closely by actors of economic management in Turkey. In this context, it is recommended that alternative energy resources be given more attention to prevent a decrease in industrial production due to rises in oil prices in in Turkey, which is strongly dependent on oil. In order to reduce the country's dependence on external sources, energy production should be increased by allocating funds and incentives for renewable energy sources such as solar, geothermal, and wind energy which have a high potential for energy capacity. It is also essential to produce industrial products such as high-speed trains and electric cars, which run on electrical energy instead of oil.

Peer-review: Externally peer-reviewed.

Conflict of Interest: The author has no conflict of interest to declare.

Grant Support: The author declared that this study has received no financial support.

\section{References}

Ahmed, H. J. A. and Wadud, M. (2011). Role of oil price shocks on macroeconomic activities: An SVAR approach to the Malaysian economy and monetary responses. Energy Policy, 39, 8062-8069. https://doi.org/10.1016/j. enpol.2011.09.067.

Atukeren, E. (2011). Granger-Nedensellik Sınamalarına Yeni Yaklaşımlar. Atatürk Ü. İ̈BF Dergisi, 10. Ekonometri ve İstatistik Sempozyumu Özel Sayıs1, 137-153.

Ayadi, O. F. (2005). Oil price fluctuations and the Nigerian economy. OPEC Review. https://doi. org/10.1111/j.0277-0180.2005.00151.x.

Bayraktutan, Y. and Solmaz, A. R. (2019). Petrol Fiyatları ve Enflasyon İlişkisi: Seçilmiş Petrol İthalatçısı Ülkeler İçin Panel Veri Analizi. Kocaeli Üniversitesi Sosyal Bilimler Dergisi, 37, 279-291.

Bektur, Ç. and Malcıoğlu, G. (2017). Kredi Temerrüt Takasları ile BIST 100 Endeksi Arasındaki İlişki: Asimetrik Nedensellik Analizi. AIB̈̈̈ Sosyal Bilimler Enstitüsü Dergisi, 17 (3), 73-83.

Central Bank of the Republic of Turkey (CBRT) (2021, February 15). Electronic Data Delivery System (EDDS), Retrieved from https://evds2.tcmb.gov.tr/index.php?/evds/serieMarket. 
Cologni, A. and Manera, M. (2008). Oil prices, inflation and interest rates in a structural cointegrated VAR model for the G-7 countries. Energy Economics, 30, 856-888. https://doi.org/10.1016/j.eneco.2006.11.001.

Cunado, J. and DeGracia, P. F. (2005). Oil prices, economic activity and inflation: evidence for some Asian countries. The Quarterly Review of Economics and Finance, 45 (1), 65-83. https://doi.org/10.1016/j. qref.2004.02.003.

Destek, M. A. and Okumuş, İ. (2016). Satın Alma Gücü Paritesi Hipotezi Geçerliliğinin Fourier Birim Kök Testleri ile İncelenmesi: OECD Ülkeleri Örneği. Gaziantep University Journal of Social Sciences, 5 (1), $73-87$.

Dickey, D. A., Fuller, W. A. (1979). Distribution of estimators for autoregressive time series with a unit root. Journal of the American Statistical Association, 74, 427-431. https://doi.org/10.2307/2286348.

Doğan, B., Eroğlu, Ö. and Değer, O. (2016). Enflasyon ve Faiz Oranı Arasındaki Nedensellik İlişkisi: Türkiye Örneği. Çankırı Karatekin Üniversitesi İktisadi ve İdari Bilimler Fakültesi Dergisi, 6 (1), 405-425.

Dursun, A. and Özcan, M. (2019). Enerji Fiyat Değişimleri İle Borsa Endeksleri Arasındaki İlişki: OECD Ülkeleri Üzerine Bir Uygulama. Muhasebe ve Finansman Dergisi, 82, 177-198. https://10.25095/mufad.536069.

Ecevit, E. and Çetin, M. (2016). Ekonomik Büyüme ve Çevre Kirliliğinin Sağl1k Üzerindeki Etkisi: Türkiye İle İlgili Ampirik Kanıt. Erciyes Üniversitesi İktisadi ve İdari Bilimler Fakültesi Dergisi, 48, 83-98.

Erkuş, S. and Karamelikli, H. (2016). Türkiye'de Tüketici Fiyatları ile Ham Petrol Fiyatları Arasındaki İlişkinin Asimetrik Analizi. Euroasian Conference on Business and Economics IV (ECBE2016), Bişkek-Kırgızistan, 18-20 May1s 2016, 1-14.

Eyüboğlu, K. and Eyüboğlu, S. (2016). Doğal Gaz ve Petrol Fiyatları ile BIST Sanayi Sektörü Endeksleri Arasındaki İlişskinin İncelenmesi. Journal of Yasar University, 11 (42), 150-162.

Gokmenoglu, K., Azin, V. and Taspinar, N. (2015). The Relationship between Industrial Production, GDP, Inflation and Oil Price: The Case of Turkey. Procedia Economics and Finance, 25, 497-503. https://doi.org/10.1016/ S2212-5671(15)00762-5.

Gövdeli, T. (2016). Türkiye'de Eğitim-Ekonomik Büyüme İlişkisi: Yapısal Kırılmalı Birim Kök ve Eşbütünleşme Analizi. Niğde Üniversitesi İktisadi ve İdari Bilimler Fakültesi Dergisi, 9 (3), 223-238.

Güder, F. and Kahıloğulları, A. (2015). Enerji Fiyatlarının Sanayi Üretimi Üzerine Etkisi: Türkiye Örneği (20052014). 1. Uluslararasi Avrasya Enerji Sorunları Sempozyumu, 28-30 May1s 2015, İzmir, 365-373.

Gündoğan, H. and Tok, D. (2019). Petrole Bağımlı Ülkelerde Petrol Fiyatlarının Sanayi Üretimine Etkisi: Panel Nedensellik Çalışması. Ege Akademik Bakış, 19 (1), 131-140. https://10.21121/eab.2019148769.

Haliloğlu, E. Y. and Tutu, B. E. (2018). Türkiye İçin Kısa Vadeli Elektrik Enerjisi Talep Tahmini. Journal of Yasar University, 13 (51), 243-255.

Hatemi-J, A. (2012). Asymmetric Causality Tests With An Application. Empirical Economics, 43, 447-456. https:// doi.org/10.1007/s00181-011-0484-X.

Kalkavan, H., Eti, S. and Yüksel, S. (2020). Türkiye'deki Bankacılık Sektörü, Sanayi Gelişimi ve Ekonomik Büyüme Arasındaki İlişkinin Var Analizi İle İncelenmesi. Akademik Araştırmalar ve Çalışmalar Dergisi, 12 (22), 56-74.

Karadaş, H. A. and Koşaroğlu, Ş. M. (2019). Petrol Şoklarının Türkiye Ekonomisine Uzun Dönem Makroekonomik Etkileri: Svar Analizi. Anadolu Üniversitesi İktisadi ve İdari Bilimler Fakültesi Dergisi, 20 (3), 40-59.

Kızılkaya, O. (2018). Türkiye’de Turizm Gelirleri ve Büyüme İlişkisinin Bootstrap Nedensellik Testi İle İncelenmesi. Dicle Üniversitesi Sosyal Bilimler Enstitüsü Dergisi, 21, 218-227.

Koçak, S., Balan, F. and Albayrak, B. (2017). Türkiye Ekonomisinde Petrol Fiyatları ve Enflasyon İlişkisi: Ampirik Analiz. Journal of Life Economics, 4 (4), 261-273.

Kumar, S. (2009). The Macroeconomic Effects of Oil Price Shocks: Empirical Evidence for India. Economics Bulletin, 29 (1), 15-37. 
LeBlanc, M. and Chinn, M. D. (2004). Do High Oil Prices Presage Inflation? The Evidence from G-5 Countries. UC Santa Cruz Economics Working Paper, No. 561. http://dx.doi.org/10.2139/ssrn.509262.

Öruç, E. (2017). İkiz Açık Hipotezinin Türkiye İçin Testi: Stock-Watson Yöntemi İle Uzun Dönemli Analiz (19502015). Gümüşhane Üniversitesi Sosyal Bilimler Enstitüsü Elektronik Dergisi, 8 (19), 260-281.

Özdemir, S. and Akgül, I. (2015). Ham Petrol ve Benzin Fiyatlarının Sanayi Üretimine Etkisi: MS-VAR Modelleri ile Analizi. Ege Akademik Bakış, 15 (3), 367-378.

Sadeghzadeh, K. (2018). Borsanın Psikolojik Faktörlere Duyarlılığı: Oynaklık Endeksi (VIX) ve Tüketici Güven Endeksi (TGE) İle BIST100 Endeksi Arasındaki İlişkiler. C. Ü. İktisadi ve İdari Bilimler Dergisi, 19 (2), 238253.

Sek, S. K. (2017). Impact of oil price changes on domestic price inflation at disaggregated levels: Evidence from linear and nonlinear ARDL modeling. Energy, 130, 204-217. http://dx.doi.org/10.1016/j.energy.2017.03.152.

Tütüncü, A. and Kahveci, Ş. (2020). Türkiye'de Petrol Fiyatlarının Sanayi Üretim Endeksi Ve İşsizlik Oranı Üzerindeki Etkisi. Hacettepe Üniversitesi İktisadi ve İdari Bilimler Fakültesi Dergisi, 38 (4), 847-867.

Uçan, O. and Bozkaya, Ş. (2019). Petrol Fiyatlarındaki Değişkenlik ve Makroekonomik Etkileri: İskandinav Ülkeleri Örneği. III. Uluslararası Eğitim Bilimleri ve Sosyal Bilimler Sempozyumu, 25-27 Haziran 2019 , Nevşehir, 650-658.

Yavuz, N. Ç. (2006). Türkiye’de Turizm Gelirlerinin Ekonomik Büyümeye Etkisinin Testi: Yapısal Kırılma Ve Nedensellik Analizi. Doğuş Üniversitesi Dergisi, 7 (2), 162-171.

Yıldırım, M., Bayar, Y. and Kaya, A. (2014). Enerji Fiyatlarının Sanayi Sektörü Hisse Senedi Fiyatları Üzerindeki Etkisi: Borsa İstanbul Sanayi Sektörü Şirketleri. Muhasebe ve Finansman Dergisi, 62, 93-108.

Yıldırtan, D. Ç. and Berk, N. (2017). Makroekonomik Denge İçin Petrol Fiyatları Önemli Midir? Marmara Üniversitesi İktisadi ve İdari Bilimler Dergisi, 39 (2), 487-502. https://doi.org/10.14780/muiibd.384149.

Zhao, L., Zhang, X., Wang, S. and Xu, S. (2016). The effects of oil price shocks on output and inflation in China. Energy Economics, 53, 101-110. http://dx.doi.org/10.1016/j.eneco.2014.11.017. 
